TECHNICAL NOTES AND MANUALS

\title{
Budget Classification
}

Prepared by Davina Jacobs, Jean-Luc Hélis, and Dominique Bouley

Fiscal Affairs Department 


\section{INTERNATIONAL MONETARY FUND}

Fiscal Affairs Department

\section{Budget Classification}

Prepared by Davina Jacobs, Jean-Luc Hélis, and Dominique Bouley Authorized for distribution by Carlo Cottarelli

December 2009

DISCLAIMER: This Technical Guidance Note should not be reported as representing the views of the IMF. The views expressed in this Note are those of the authors and do not necessarily represent those of the IMF or IMF policy.

\begin{tabular}{|l|l|}
\hline JEL Classification Numbers: & $\mathrm{H1}, \mathrm{H} 5, \mathrm{H6}, \mathrm{H7}$ \\
\hline Keywords: & $\begin{array}{l}\text { budget, budget classification, chart of accounts, government finance } \\
\text { statistics, poverty-reducing expenditure, program budgeting, public } \\
\text { financial management }\end{array}$ \\
\hline Authors' E-Mail Addresses: & djacobs@imf.org; jhelis@imf.org; dc.bouley@yahoo.com \\
\hline
\end{tabular}




\section{TECHNICAL NOTES AND MANUALS}

\section{Budget Classification}

\section{Prepared by Davina Jacobs, Jean-Luc Hélis, and Dominique Bouley}

\section{This technical note ${ }^{1}$ addresses the following main issues:}

- Why is a budget classification system important?

- What are the main features of a sound budget classification system?

- How should a budget classification system be structured?

- What is the relationship between budget classification and the chart of accounts (COA)?

- What are the preconditions for successful implementation of a new budget classification system?

- What are likely to be the critical steps and milestones in the reform of budget classification?

\section{Why Is a Budget Classification System Important?}

Budget classification is one of the fundamental building blocks of a sound budget management system, as it determines the manner in which the budget is recorded, presented and reported, and as such has a direct impact on the transparency and coherence of the budget.

In countries where the budget nomenclature is weak, upgrading the budget classification system should itself be considered a basic step—indeed a precondition—before embarking on other reforms of public financial management (PFM) such as introducing a computerized financial management information system, a medium-term expenditure framework (MTEF), or a resultsbased budgeting system.

A budget classification system provides a normative framework for both policy decision making and accountability. Classifying expenditures and revenues correctly is important for (1) policy formulation and performance analysis; (2) allocating resources efficiently among sectors; (3) ensuring compliance with the budgetary resources approved by the legislature; and (4) day-to-day

\footnotetext{
${ }^{1}$ An earlier version of this note was issued as part of a series of technical notes on the IMF's Public Financial Management Blog (http://blog-pfm.imf.org). This note has benefited from peer review by present and former Fiscal Affairs Department colleagues including M. Lazare, B. Dorotinsky, R. Allen, A. Khan, I. Lienert, F. Michel, I. Fainboim, and M. Pessoa.
} 
administration of the budget. Once established on a sound basis, a classification scheme should not be substantially changed unless there are strong reasons; a stable classification facilitates both the analysis of trends in fiscal policy over time and intercountry comparisons.

\section{What Are the Main Features of a Sound Budget Classification System?}

In order to meet the requirement of providing accurate information to policymakers, government managers, the legislature, and the broader public, the primary aim of a classification scheme should be to ensure that the budget complies with three key principles of sound budget management:

- The principle of comprehensiveness requires that the budget cover all government entities and institutions undertaking government operations, and present a consolidated and complete view of these operations.

- The principle of unity requires that the budget include all revenues and expenditures of all government entities undertaking government operations. This principle is important to ensure that the budget is effective in constraining total and sectoral government expenditure, and in promoting greater efficiency in the allocation of resources.

- The principle of internal consistency between different components of the budget requires, in particular, that the current expenditure needed for the operations and maintenance of past investment projects be fully reflected in the budget. Moreover, this principle implies that there should be a unitary budget system in which responsibilities for preparing and executing the budgets for current and capital (or development) spending are consolidated within a single central fiscal agency, usually the ministry of finance.

Different approaches to budgeting often have a strong influence on the structure and organization of the classification system. For example, compliance budgeting focuses on ensuring that the collection and use of resources are consistent with the budget laws, which in turn depend on having an accurate classification of these transactions and the organizations responsible for receiving revenues or incurring expenditures. Policy formulation and allocative efficiency concerns are the basis of a classification of expenditure by function and program. A detailed classification of programs by activity or output is required if operational performance is being assessed. Fiscal control requires at least an economic classification based on clear concepts (e.g., separating borrowing from receipts). Meeting these different and sometimes conflicting requirements calls for a pragmatic and flexible approach.

A sound system of budget classification should at a minimum comprise a classification of revenues into various categories, and administrative, economic, and functional classifications of expenditures. ${ }^{2}$ The administrative classification identifies the entity that is responsible for managing the public funds concerned, such as the ministry of education and health or, at a lower level, schools and

2 The structure and main principles of a basic budget classification system are developed in Section III. 
hospitals. The economic classification identifies the type of expenditure incurred, for example, salaries, goods and services, transfers and interest payments, or capital spending. The functional classification categorizes expenditure according to the purposes and objectives for which they are intended. All three classifications are essential for users of budget information.

Many countries use additional classification schemes to enhance transparency and accountability and to better manage their finances (for further details, see Section IV below). However, it is necessary to be careful in expanding the different types of classification to be used. Such an expansion could possibly lead to unreliable information, due to the complexity of the budget nomenclature. It also requires more capacity and resources to generate the required information and maintain the system. Some of these analytic needs can be addressed through ad hoc data calls rather than hard-coding them directly into the budget classification.

The following features are considered to be critical to a system of budget classification if it is to generate useful, timely, and reliable information: ${ }^{3}$

- Distinction between administrative and economic classifications. The economic and administrative classifications provide different kinds of information. The former provides data on types of revenues or expenditures (for example, salaries or goods and services), while the latter provides data on the public sector organizations that incur expenditures or receive revenues. An administrative classification of expenditure is needed to identify responsibilities for the main blocks of public expenditure and for day-to-day administration of the budget. Expenditures may be divided into separate subcategories for each ministry, department, or public entity.

- The independence of economic and administrative categories. It is important to the soundness of a classification system that the economic and administrative categories be independent of each other. For example, the economic classification may be used to indicate whether government receipts derive from tax revenues or the sale of goods or services, but not whether this income should be attributed to a central government ministry or department, or to a subnational entity. ${ }^{4}$

- The use of the functional classification. A "functional" classification organizes government activities according to their broad objectives or purposes (e.g., education, social security, housing, etc.). It is independent of the government's administrative or organizational structure. Such a classification is especially useful in analyzing the allocation of resources among sectors. It may also be used for tracking poverty-reducing expenditures. A sound and stable functional classification is required to generate the data that are necessary to produce historical surveys

\footnotetext{
${ }^{3}$ In some countries, a distinction between revenues, expenditures, and transactions in financial assets and liabilities would be also needed. This distinction is important for the purposes of measuring the impact of fiscal policies.

${ }^{4}$ In some countries, the budget is implemented through the use of specific projects which, in some cases, may be financed by donor aid. A project is a single, indivisible activity with a fixed time schedule and a dedicated budget. Some projects are managed through special organizational arrangements and have their own budgets and bank accounts. In such cases, the project could be considered as a subdivision of the spending unit responsible for its management.
} 
and analyses of government spending, and to compare data from different fiscal years. The Classification of the Functions of Government (COFOG) established by the United Nations is a widely accepted international standard in this field (see also Section VI).

- Mutual exclusivity. Every line item in a well-designed budget classification system should be independent of all other line items, as explained in the following section.

\section{The Structure of a Budget Classification System}

The detailed structure of a budget classification system needs to be well designed if meaningful and reliable information is to be extracted and the system is to be capable of modification in the future. These core features are embedded in its coding system. The IMF's Government Finance Statistics Manual (GFSM 2001) provides a standard framework for developing a new budget classification structure or improving an existing one (see Box 1$){ }^{5}$

\section{The GFSM 2001, however, was developed primarily as a statistical reporting framework} and is generally not sufficient for the purposes of developing a budget classification system. It focuses on revenues, and economic and functional reporting for statistical purposes, while a budget classification system is also an instrument of policy formulation, administration of the budget, and accounting. As a result, the classification system for both expenditures and revenues may need to be adapted to meet the needs of budget preparation and execution. Some countries (e.g., Brazil) have developed satisfactory budget classifications, adapted to their needs and constraints, without using the GFS framework.

\section{Classification of Revenues ${ }^{6}$}

Following the GFSM 2001 framework, revenue is classified according to the following categories: (1) taxes, (2) social contributions, (3) grants, and (4) other revenues. For taxes, the classification scheme is determined mainly by the base on which the tax is levied (e.g., income, expenditure, property assets, savings, etc.).

The GFSM 2001 framework allows revenues to be recorded on an accrual basis; that means creating a future claim or entitlement for the government to receive taxes or other types of revenue at the time that activities, transactions, or other events occur. The application of this general rule to the various types of revenue should be indicated in each section of the classification as necessary. ${ }^{7}$

\footnotetext{
5 This framework was developed jointly by the IMF, the United Nations (UN), the Organization for Economic Cooperation and Development (OECD), and the Statistical Office of the European Union (Eurostat). GFSM 2001 also incorporates the Classification of the Functions of Government (COFOG) of the OECD and the UN.

6 The GFSM 2001 classification system for government revenues is presented in Annex II.

7 This can be a problem, however, if the revenue collection rate is poor, as is the case in many low-capacity countries.
} 


\section{Box 1. Using the Government Finance Statistics Manual (GFSM 2001) to Design Budget Classifications}

The GFSM 2001 provides some specific guidance on certain desirable features of economic and functional classifications:

- The GFSM 2001 economic classification is presented in Annex III. GFSM 2001 is defined on an accrual basis with a view to creating statistical comparability between fiscal reports and national accounts. However, with the exception of the consumption of fixed capital, the line items in the economic classification of government operations, as presented in GFSM 2001, apply to the cash and the accrual bases equally. ${ }^{1}$ In a number of cases, the standard GFS tables include net items. Such items can be sufficient for the purpose of macroeconomic analysis, but not for budget formulation and management. In the government accounts, gross flows should be recorded. Thus, from the policy formulation point of view, the acquisition of financial assets for new policy purposes (e.g. lending to public enterprise) should be separated from the repayments of loans, which are the result of previous policy decisions.

- The GFSM 2001 functional classification ${ }^{2}$ corresponds to the United Nations Classification of the Functions of Government (COFOG). ${ }^{3}$ Adopting COFOG instead of a customized classification presents some advantages. Such an approach is already established and well documented in the GFS manual. It facilitates international comparisons. Many countries may decide, however, to expand the COFOG system to accommodate their actual program structures and deal with specific policy issues. This is recognized in the GFSM 2001. In such cases, a mapping table between COFOG and the functional (and program) classification used in a particular country, or between that country's organizational classification and COFOG, should be established in order to prepare reports that may be required using the COFOG system.

\footnotetext{
${ }^{1}$ In the GFSM 2001 economic classification, the acquisition of a nonfinancial asset by purchase or barter does not affect net worth, and the transaction is not an expense. It is a transaction in nonfinancial assets. When ownership of an asset is given up without receiving anything of value in return, the net worth of the unit has decreased and the expense is recorded as a type of capital transfer, such as a capital grant.

2 The GFSM 2001 functional classification is presented in Annex IV.

${ }^{3}$ The GFSM 2001 functional classification is not limited to expense transactions. Acquisitions of nonfinancial assets can also be classified using the functional classification. In addition, the economic and the functional classification can be cross-classified to show the type of transactions engaged in to carry out a given function.

\begin{abstract}
${ }^{4}$ However, this does not mean that it is acceptable for a country to mix up different functions, or misclassify an education function as, for example, immigration, or to create multiple functions to capture what GFSM 2001 considers as a single function.
\end{abstract}

\section{Classification of Expenditures}

Expenditures are typically recorded against the administrative, economic, and functional classifications. The budget code for each transaction should present, in specific categories, all relevant information regarding that transaction. Table 1 provides an illustrative example 
Table 1. Illustrative Budget Classification Scheme for Expenditures

\begin{tabular}{|c|c|c|c|c|c|c|c|}
\hline \multicolumn{2}{|c|}{ Administrative Classification } & \multicolumn{3}{|c|}{ Economic Classification } & \multicolumn{3}{|c|}{ Functional Classification } \\
\hline Title & Chapter & Section & Article & Paragraph & Main function & Function & $\begin{array}{l}\text { Secondary } \\
\text { function }\end{array}$ \\
\hline Ministry & $\begin{array}{l}\text { Managing } \\
\text { unit }\end{array}$ & Main classification & Subclassification & $\begin{array}{l}\text { Supplementary } \\
\text { information }\end{array}$ & Division & Group & Class \\
\hline $\begin{array}{c}\text { Ministry of Agriculture } \\
\text { and Forestry }\end{array}$ & $\begin{array}{l}\text { General Directorate } \\
\text { for Agriculture }\end{array}$ & Expenses & $\begin{array}{l}\text { Compensation } \\
\text { of employees }\end{array}$ & $\begin{array}{c}\text { Wages and salaries } \\
\text { in cash }\end{array}$ & Economic Affairs & $\begin{array}{l}\text { Agriculture Forestry } \\
\text { Fishing Hunting }\end{array}$ & Agriculture \\
\hline 2 characters & 2 characters & 1 character & 1 character & 2 characters & 3 characters & 1 character & 1 character \\
\hline
\end{tabular}

The fundamental principle of the classification scheme for expenditure, illustrated in this table, is that each classification has defining characteristics that are different from, and independent of, the other two. It is important that every expenditure item and transaction be attributed to each of the three classifications shown above clearly and unambiguously, without duplication, overlap or repetition.

Table 2. Incorporating Additional Features into the Budget Classification Scheme

\begin{tabular}{|c|c|c|c|c|c|c|c|c|c|c|}
\hline \multicolumn{3}{|c|}{ Administrative Classification } & \multicolumn{3}{|c|}{ Economic Classification } & \multicolumn{3}{|c|}{ Functional Classification } & \multicolumn{2}{|c|}{ Additional Classifications } \\
\hline Title & Chapter & Geographic & Section & Article & Paragraph & $\begin{array}{c}\text { Main } \\
\text { function }\end{array}$ & Function & $\begin{array}{c}\text { Secondary } \\
\text { function }\end{array}$ & $\begin{array}{l}\text { Source of } \\
\text { financing }\end{array}$ & Beneficiary \\
\hline Ministry & $\begin{array}{l}\text { Managing } \\
\text { unit }\end{array}$ & Zip code & $\begin{array}{c}\text { Main } \\
\text { classification }\end{array}$ & Subclassification & $\begin{array}{c}\text { Other } \\
\text { information }\end{array}$ & Division & Group & Class & General budget & Public entity \\
\hline $\begin{array}{c}\text { Ministry of } \\
\text { Agriculture } \\
\text { and Forestry }\end{array}$ & $\begin{array}{c}\text { General } \\
\text { Directorate } \\
\text { for } \\
\text { Agriculture }\end{array}$ & $\begin{array}{c}\text { Assigned by } \\
\text { the Statistics } \\
\text { Office }\end{array}$ & Expenses & $\begin{array}{c}\text { Compensation of } \\
\text { employees }\end{array}$ & $\begin{array}{l}\text { Wages and } \\
\text { salaries in } \\
\text { cash }\end{array}$ & $\begin{array}{c}\text { Economic } \\
\text { Affairs }\end{array}$ & $\begin{array}{c}\text { Agriculture } \\
\text { Forestry Fishing } \\
\text { Hunting }\end{array}$ & Agriculture & $\begin{array}{l}\text { Other sources } \\
\text { include donor } \\
\text { aid projects, } \\
\text { resource } \\
\text { revenue funds, } \\
\text { etc. }\end{array}$ & $\begin{array}{l}\text { Including } \\
\text { geographic } \\
\text { codes if } \\
\text { required }\end{array}$ \\
\hline $\begin{array}{c}2 \\
\text { characters }\end{array}$ & $\begin{array}{c}2 \\
\text { characters }\end{array}$ & $\begin{array}{c}4 \\
\text { characters }\end{array}$ & $\begin{array}{c}1 \\
\text { character }\end{array}$ & $\begin{array}{c}1 \\
\text { character }\end{array}$ & $\begin{array}{c}2 \\
\text { characters }\end{array}$ & & $\begin{array}{c}5 \\
\text { characters }\end{array}$ & & $\begin{array}{c}1 \\
\text { character }\end{array}$ & $\begin{array}{c}6 \\
\text { characters }\end{array}$ \\
\hline
\end{tabular}

CInternational Monetary Fund. Not for Redistribution 
of a classification scheme for expenditures, comprising the three main classifications, eight subclassifications (title, chapter, etc.), and thirteen characters. The names assigned to these subclassifications can differ from one country to another.

\section{Additional Forms of Budget Classification}

In addition to the administrative, economic, and functional classifications, other forms of classification may provide complementary information, in particular:

- Classification by geographical location of the administrative unit, taxpayer, or the recipient of government transfers and subsidies;

- Classification of the beneficiaries of government transfers and subsidies;

- Classification of the sources of financing and counterpart funds used for recording external loans and grants. ${ }^{8}$

Table 2 illustrates the integration of these additional segments in the previous classification scheme, thus creating a code that comprises 24 characters.

\section{Using the Budget Classification Scheme to Track Poverty-Reducing Expenditures}

A sound budget classification scheme should make it possible to determine the budget lines affected by poverty-reducing expenditure. In many countries the poverty-reducing strategy program (PRSP) or other government documents define pro-poor expenditures. The task is, therefore, to relate poverty-related spending identified in a PRSP to the government's existing budget classification scheme, so that timely and periodic accounting reports can be prepared for tracking purposes. Ideally, a program classification should be used for this purpose or, if this is not available, a functional classification (at least to the subfunction level). A challenge to this approach may be the level of detail to which a PRSP identifies spending: in some cases, the spending categories may be too general or broad for the intended purpose (e.g., "primary education" or "improved health"); in other cases, they may be too narrow (e.g., "a new bore-hole in village Y").

Based on the PRSP, pro-poor spending may be identified by using a binary rating system for each transaction (e.g., by assigning the score "0" for nonpoverty-reducing expenditures, and "1" for poverty-reducing expenditures). However, the use of such a system gives only global information. It must be combined with the other classifications in order to give relevant data on povertyreducing expenditures.

The use of the functional classification has several advantages for tracking poverty-reducing expenditures. Such expenditures can be clearly identified from the budget data, and the links between the PRSP and the annual budget can be analyzed. The identification can be made by using

8 Such a classification has to be used carefully. First, it is contrary to the principle of comprehensiveness (the budget should present a consolidated picture of revenues and expenditures). Second, its use should not result in implementing complex earmarking mechanisms to execute the budget. 
Table 3. Example of the Identification of Poverty-Reducing Expenditures

Using a Bridge Table between the PRSP and the GFMS 2001 Functional Classification

\begin{tabular}{|c|c|c|}
\hline PRSP & Corresponding Functions & Functional Code \\
\hline Improving populations' health & Health (all subfunctions) & 707 \\
\hline & Culture & 70821 \\
\hline Access to drinking water & Water supply & 70631 \\
\hline & R\&D Housing and community amenities & 70661 \\
\hline Environmental development & Waste management & 70511 \\
\hline & Protection of biodiversity and landscape & 70541 \\
\hline
\end{tabular}

a bridge table that links the data in the PRSP and the functional classification. Table 3 gives an illustrative example of the identification of poverty-reducing expenditures using such an approach. ${ }^{9}$

\section{Program Classification ${ }^{10}$}

A program is a set of activities that meets specific policy objectives of the government (e.g., preprimary education or the development of crop production). In contrast to a functional classification, a classification by program takes into account the government's policy objectives and how these policies will be implemented. Programs may be subdivided into homogeneous categories called activities (e.g., the vaccination activity within a disease prevention program), which in turn may encompass a series of related initiatives and projects.

Classifying expenditures by program can serve two purposes: (1) identifying and clarifying the goals and objectives of government spending and (2) monitoring operational performance through performance indicators, which may relate to the inputs, outputs, or outcomes of a particular program. ${ }^{11}$ A classification by program can contribute to improved transparency and accountability, and help link inputs to objectives or outcomes.

\footnotetext{
${ }^{9}$ In this example, all expenditures in the "health" category are considered to be poverty-reducing (code \# 707 in Table 3 above), while for other categories such as "water supply" only the relevant subfunctions are defined as poverty-reducing activities (e.g., "access to drinking water" with code \# 70631).

10 See M. Robinson and H. van Eden, 2007, "Program Classification", in Performance Budgeting: Linking Funding and Results, ed. by Robinson, pp. 63

${ }^{11}$ Inputs are the resources to produce outputs. They are usually expressed as amounts of expenditure of or resources themselves (e.g. the number of employee/days). Outputs mean the products and services produced directly by a program or activity. Outputs are important, for example, in setting targets for staff to achieve and measuring performance, but do not in themselves indicate the extent to which progress has occurred towards achieving a program's ultimate policy objective or purpose. Outcomes represent the economic or social changes brought about by a policy measure, program, or activity. Outcomes are distinct from outputs, which measure the immediate effects of a program or activity. For example, the outcome of a random breath-testing campaign conducted by the police may be a decline in drunk driving, while one of the outputs could be the number of drivers charged with exceeding the legal alcohol limit. See Allen and Tommasi (2001).
} 
When establishing a program classification, it is important to ensure that (1) clear responsibility for managing the program, and accountability for its results, are allocated to a specific unit and program manager within the ministry or department concerned ${ }^{12}$ and (2) the requirements for data collection and analysis are kept within reasonable bounds. A programmatic approach has the advantage of encouraging managers in each organization to clearly define their objectives and to consider what results have been achieved. It is thus often linked to the development of a performance-related approach to budgeting. As for the administrative classification, there is no specific international norm for codifying the programs. The program classification depends on the needs in each country.

Table 4 gives an illustrative example of a budget classification scheme by program, which replaces the administrative classification shown in Table 2. In this example, each program is assumed to be managed by a specific ministry, which is the easiest way to introduce program budgeting to ensure accountability and to track the relevant expenditures. When a program covers several ministries, ${ }^{13}$ this approach cannot be used, however, and complex bridge tables are necessary to identify which part of the program each ministry is responsible for.

\section{The Relationship between the Budget and Accounting Classifications}

In most countries, it is generally considered to be good practice for the budget classification and the accounting classification (otherwise known as the financial reporting classification or "chart of accounts") to be completely integrated. ${ }^{14}$ An integrated budget and accounting classification would incorporate relevant asset and liability accounts. These mainly comprise financial accountsrecording government operations with the central bank, commercial banks, and other financial entities-and suspense accounts. Such an approach is used in particular in the Anglophone countries, where the chart of accounts (COA) is a coding framework for recording budgetary and financial data in the government accounts. ${ }^{15}$ An example of such an approach is illustrated in Annex I. ${ }^{16}$

\footnotetext{
12 This may in turn require a revision of the administrative structure of ministries, which is often quite difficult to implement.

13 Establishing programs covering several ministries is generally not advisable.

${ }_{14}$ The budget classification refers to all coding schemes that are used to define both revenue and expenditure transactions at budget planning, budget approval, and budget execution. The budget classification, at some level of aggregation, is used to present the budget to the parliament for approval and, once approved, provides the legal expenditure limit, in the case of appropriations, and the approved plan in the case of revenues. The accounting classification (or financial reporting classification) is the chart of accounts that is used for administrating, recording, and reporting on financial transactions.

15 This approach has also been used in countries such as Brazil and Mozambique for example.

16 See also A. Khan and S. Mayes, 2009, "Transition to Accrual Accounting", IMF Technical Notes and Manuals. This note is available on the IMF's PFM Blog at http://blog-pfm.imf.org.
} 
Table 4. Illustrative Budget Classification Scheme Including the Program Classification

\begin{tabular}{|c|c|c|c|c|c|c|c|c|c|c|c|c|}
\hline \multicolumn{5}{|c|}{ Program Classification } & \multicolumn{3}{|c|}{ Economic Classification } & \multicolumn{3}{|c|}{ Functional Classification } & \multicolumn{2}{|c|}{$\begin{array}{c}\text { Additional } \\
\text { Classifications }\end{array}$} \\
\hline Ministry & Program & Manager & Unit & $\begin{array}{c}\text { Sub- } \\
\text { program }\end{array}$ & Section & Article & Paragraph & $\begin{array}{c}\text { Main } \\
\text { function }\end{array}$ & Function & $\begin{array}{l}\text { Secondary } \\
\text { function }\end{array}$ & $\begin{array}{l}\text { Source of } \\
\text { financing }\end{array}$ & Beneficiary \\
\hline Ministry & Program & $\begin{array}{l}\text { Program } \\
\text { manager }\end{array}$ & $\begin{array}{c}\text { Managing } \\
\text { unit }\end{array}$ & Subprogram & $\begin{array}{c}\text { Main } \\
\text { classification }\end{array}$ & Subclassification & Other Information & Division & Group & Class & $\begin{array}{l}\text { General } \\
\text { budget }\end{array}$ & Public entity \\
\hline $\begin{array}{c}\text { Ministry of } \\
\text { Agriculture } \\
\text { and } \\
\text { Forestry }\end{array}$ & $\begin{array}{l}\text { Assisting } \\
\text { the } \\
\text { breeding }\end{array}$ & $\begin{array}{c}\text { General } \\
\text { Director for } \\
\text { Agriculture }\end{array}$ & $\begin{array}{c}\text { Human } \\
\text { Resources } \\
\text { Division }\end{array}$ & $\begin{array}{c}\text { Training } \\
\text { of poultry } \\
\text { farmers }\end{array}$ & Expenses & $\begin{array}{l}\text { Use of goods } \\
\text { and services }\end{array}$ & Training of staff & $\begin{array}{c}\text { Economic } \\
\text { Affairs }\end{array}$ & $\begin{array}{c}\text { Agriculture } \\
\text { Forestry } \\
\text { Fishing } \\
\text { Hunting }\end{array}$ & Agriculture & $\begin{array}{l}\text { Or IPPTE, } \\
\text { donors, } \\
\text { and oil } \\
\text { budget }\end{array}$ & $\begin{array}{c}\text { Including } \\
\text { geographic } \\
\text { codification } \\
\text { (option) }\end{array}$ \\
\hline $\begin{array}{c}2 \\
\text { characters }\end{array}$ & $\begin{array}{c}1 \\
\text { character }\end{array}$ & $\begin{array}{c}1 \\
\text { character }\end{array}$ & $\begin{array}{c}2 \\
\text { characters }\end{array}$ & $\begin{array}{c}1 \\
\text { character }\end{array}$ & $\begin{array}{c}1 \\
\text { character }\end{array}$ & $\begin{array}{c}1 \\
\text { character }\end{array}$ & $\begin{array}{c}2 \\
\text { characters }\end{array}$ & & $\begin{array}{c}5 \\
\text { characters }\end{array}$ & & $\begin{array}{c}1 \\
\text { character }\end{array}$ & $\begin{array}{c}6 \\
\text { characters }\end{array}$ \\
\hline
\end{tabular}


In some countries, however, the accounting and budgeting classifications are entirely separate, ${ }^{17}$ or only partially integrated. ${ }^{18}$ In particular, they can differ in terms of structure and information content.

In such cases, the absence of one-to-one correspondence between entries (or transactions) recorded against the budget and accounting classifications generates a loss of information. It is then impossible to identify with certainty the accounting implications of a given budgetary operation; and reciprocally, identical accounting transactions may not reflect systematically equivalent budgetary operations.

In practice, this issue can be solved in many different ways, including the following:

- Implementing a central database for recording budgetary and accounting transactions, so that any entry in the budgetary classification is systematically associated with an entry in the accounts.

- Introducing a separate presentation in the accounting classification to ensure the proper recording of budgetary transactions (through a specific class of operations). ${ }^{19}$

- Harmonizing the structure and coverage of both classifications, and developing bridge tables between them. ${ }^{20}$

\section{Preconditions for the Successful Implementation of a New Budget Classification}

\section{Political Ownership}

Without commitment and leadership at a high political level, it is unlikely that the reform will be successfully implemented. The support of the legislature is also desirable, not only to ensure passage of any new financial management regulations that may be required to implement the reform, but also to endorse and utilize the changed budget presentation and financial reporting that will follow.

\section{Technical Capacity}

Building capacity to implement the reform is another critical success factor. If the finance ministry has insufficient skilled and trained staff and other resources, a new budget nomenclature is unlikely to be effective. Strengthened capacity within the budget departments of line ministries and other budgetary institutions (e.g., the treasury, the external audit authority, and the national

\footnotetext{
${ }_{17}$ This is the case in Mexico, for example.

18 In Francophone countries, the integration between the budget classification and the plan compatible has been limited to the economic classification (with revenue and expenditure classes).

19 In France, for example, specific classes of auxiliary accounts were used until recently to ensure the link between accounting transactions and budgetary line items.

20 The third approach is currently used, for example, in Argentina.
} 
professional accounting bodies) is also an essential requirement. Outside consultants may be used to supplement in-house resources to develop the new systems and procedures, but are not a substitute for building adequate internal capacity.

\section{IT Systems}

Although a modern budget classification scheme can be implemented manually, in practice it is preferable to make use of an electronic system (which does not need to be sophisticated). Computer processing of budgetary transactions permits a reclassification of entries according to the main classification schemes, and strengthens functionality in areas such as administrative accounting and reporting. In many countries, a revision of the budget classification has been introduced as part of the development of an integrated and automated financial management information system (IFMIS).

\section{Critical Steps and Milestones in the Budget Classification Reform Process}

Depending on the scope of the reform, and the conditions prevailing in a country, a reform of the budget classification can be a lengthy process, in particular to achieve full integration of the budget classification and the COA. Changes are likely to be required in the legal and regulatory framework for the budget, the government's financial management and information system, and training and outreach programs to raise awareness and upgrade the skills of staff in the ministry of finance and other government entities.

An illustrative timetable for introducing a new budget classification scheme is shown in Table 5. Sufficient time should be allowed for making preparations and implementing the various steps. In most countries, work on preparing the new classification should be completed at least six months before the start of the budget year and, in the case of the COA, at least two months before its implementation. ${ }^{21}$

A transitional period of sufficient length should be allowed before the new classification system is fully operational, so that (1) the new system can be reviewed by key stakeholders, such as line ministries, the external audit authority, and the legislature; (2) operational guidelines can be developed and training performed for staff in line ministries, local budget institutions, and other entities involved in the reform; and (3) the legal framework can be amended, if necessary. Transfer of knowledge and ownership are key elements if the new classification is to be used as a foundation for preparing and executing the budget.

\footnotetext{
${ }_{21}$ Table 5 is based on FAD's experience of assisting countries in their introduction of a new budget classification system.
} 
Table 5. Suggested Timetable for Implementing a New Budget Classification, Integrated with the COA, in Fiscal Year N

\begin{tabular}{|c|l|l|l|}
\hline & Activity & $\begin{array}{l}\text { Suggested } \\
\text { Responsibility }\end{array}$ & $\begin{array}{l}\text { Complete } \\
\text { by }\end{array}$ \\
\hline 1 & $\begin{array}{l}\text { Approve, in principle, the top (chapter) } \\
\text { level classification for revenues, } \\
\text { expenditures, and financing item, and } \\
\text { complete development of draft budget } \\
\text { classification }\end{array}$ & MOF & June 30, N-2 \\
\hline 2 & $\begin{array}{l}\text { Complete review and any final } \\
\text { amendments of budget classification }\end{array}$ & $\begin{array}{l}\text { MOF, and selected } \\
\text { ministries }\end{array}$ & October 31, N-2 \\
\hline 3 & $\begin{array}{l}\text { Formally approve budget classification, } \\
\text { and submit new classification based } \\
\text { budget N-1 to Council of Ministers }\end{array}$ & MOF & December 31, N-2 \\
\hline 4 & $\begin{array}{l}\text { Complete training material for new } \\
\text { classification, and train budget entities on } \\
\text { new classification }\end{array}$ & MOF & March 31, N-1 \\
\hline 5 & $\begin{array}{l}\text { Issue budget circular on the basis of the } \\
\text { new budget classification }\end{array}$ & MOF & April N-1 \\
\hline 6 & $\begin{array}{l}\text { Submit budget requests based on new } \\
\text { budget classification to MOF }\end{array}$ & Budget entities & July 31, N-1 \\
\hline 7 & $\begin{array}{l}\text { Complete modifications to budgeting } \\
\text { records/systems }\end{array}$ & $\begin{array}{l}\text { MOF, and budget } \\
\text { entities }\end{array}$ & July 31, N-1 \\
\hline 8 & Complete development of draft COA & MOF & July 31, N-1 \\
\hline 9 & $\begin{array}{l}\text { Complete review and any final } \\
\text { amendments of COA }\end{array}$ & $\begin{array}{l}\text { MOF, selected } \\
\text { ministries, with } \\
\text { Consultants }\end{array}$ & September 30, N-1 \\
\hline 10 & Submit budget to national assembly & MOF & October, N-1 \\
\hline 11 & Formally approve COA & $\begin{array}{l}\text { Complete training material for new COA, } \\
\text { and train accounting staff }\end{array}$ & MOF \\
\hline 13 & $\begin{array}{l}\text { Amend accounting records to incorporate } \\
\text { new COA }\end{array}$ & $\begin{array}{l}\text { MOF, other budget } \\
\text { entities }\end{array}$ & Aug - Dec N-1 \\
\hline 14 & Approval of budget & Parliament & Dec N-1 \\
\hline
\end{tabular}




\section{References}

Ahmad, Ehtisham, Maria Albino-War, and Raju Singh, 2006, "Subnational Public Financial Management: The Public Financial Management Process" (Washington: International Monetary Fund).

Allen, Richard and Daniel Tommasi (ed.), 2001, Managing Public Expenditure: A Reference Book for Transition Countries, SIGMA.

Bouley, Dominique, 2004, Les défis techniques du suivi des dépenses de réduction de la pauvreté dans les pays francophones, Reflets et perspectives de la vie économique, (2004-1), tome XLIII, De Boeck University.

International Monetary Fund, 2001, Government Finance Statistics Manual (Washington: International Monetary Fund).

Khan, Abdul and Stephen Mayes, 2009, "Transition to Accrual Accounting," IMF Technical Notes and Manuals (Washington: International Monetary Fund).

Lienert, Ian, 2003, "A Comparison between Two Public Expenditure Management Systems in Africa," IMF Working Paper 03/2 (Washington: International Monetary Fund).

Potter, Barry H. and Jack Diamond, 1999, Guidelines for Public Expenditure Management (Washington: International Monetary Fund).

Robinson, Marc (ed.), 2007, Performance Budgeting: Linking Funding and Results (Washington: International Monetary Fund). 
ANNEX I. Example of a Chart of Accounts (COA) for Expenditure, Integrating the Budget Classification ${ }^{22}$

\begin{tabular}{|c|c|c|c|c|c|c|c|c|c|c|}
\hline \multicolumn{2}{|c|}{$\begin{array}{l}\text { Administrative } \\
\text { classification }\end{array}$} & \multicolumn{3}{|c|}{ Economic classification } & \multicolumn{3}{|c|}{ Functional classification } & \multicolumn{2}{|c|}{ Additional classifications } & \multirow{2}{*}{$\begin{array}{c}\begin{array}{c}\text { Financial } \\
\text { classification }\end{array} \\
\text { Financial and } \\
\text { suspense } \\
\text { accounts } \\
\text { (mainly) }\end{array}$} \\
\hline Title & Chapter & Section & Article & Paragraph & $\begin{array}{c}\text { Main } \\
\text { function }\end{array}$ & Function & $\begin{array}{l}\text { Secondary } \\
\text { function }\end{array}$ & $\begin{array}{l}\text { Source of } \\
\text { financing }\end{array}$ & Beneficiary & \\
\hline Ministry: & $\begin{array}{l}\text { Managing } \\
\text { unit: } \\
\text { (Directorate, } \\
\text { project) }\end{array}$ & $\begin{array}{c}\text { Main } \\
\text { classification }\end{array}$ & Subclassification & $\begin{array}{c}\text { Other } \\
\text { information }\end{array}$ & Division & Group & Class & $\begin{array}{l}\text { General } \\
\text { budget }\end{array}$ & Public entity & Bank account \\
\hline $\begin{array}{c}\text { Ministry of } \\
\text { Agriculture } \\
\text { and } \\
\text { Forestry }\end{array}$ & $\begin{array}{l}\text { General } \\
\text { Directorate } \\
\quad \text { for } \\
\text { Agriculture }\end{array}$ & Expenses & $\begin{array}{c}\text { Compensation of } \\
\text { employees }\end{array}$ & $\begin{array}{l}\text { Wages and } \\
\text { salaries in } \\
\text { cash }\end{array}$ & $\begin{array}{c}\text { Economic } \\
\text { Affairs }\end{array}$ & $\begin{array}{l}\text { Agriculture } \\
\text { Forestry } \\
\text { Fishing } \\
\text { Hunting }\end{array}$ & Agriculture & $\begin{array}{l}\text { Or HIPC, } \\
\text { donors, and } \\
\text { oil budget }\end{array}$ & $\begin{array}{c}\text { Including } \\
\text { geographic } \\
\text { codification } \\
\text { (option) }\end{array}$ & $\begin{array}{c}\text { Treasury } \\
\text { account at the } \\
\text { Central Bank }\end{array}$ \\
\hline $\begin{array}{c}2 \\
\text { characters } \\
\end{array}$ & $\begin{array}{c}2 \\
\text { characters } \\
\end{array}$ & $\begin{array}{c}1 \\
\text { character }\end{array}$ & $\begin{array}{c}1 \\
\text { character }\end{array}$ & $\begin{array}{c}2 \\
\text { characters } \\
\end{array}$ & $\begin{array}{c}2 \\
\text { character }\end{array}$ & $\begin{array}{c}1 \\
\text { character }\end{array}$ & $\begin{array}{c}1 \\
\text { character }\end{array}$ & $\begin{array}{c}1 \\
\text { character } \\
\end{array}$ & $\begin{array}{c}6 \\
\text { characters } \\
\end{array}$ & $\begin{array}{c}4 \\
\text { characters } \\
\end{array}$ \\
\hline
\end{tabular}

$\overline{22}$ In this example, the first four columns represent the budget classification, and the COA comprises this information and the final column (financial transactions). 


\section{ANNEX II. GFSM 2001-Classification of Revenue}

\begin{tabular}{|c|c|c|c|}
\hline \multicolumn{4}{|c|}{ Revenue } \\
\hline 11 & Taxes & 12 & Social contributions \\
\hline 111 & Taxes on income, profits, and capital gains & 121 & Social security contributions \\
\hline 1111 & Payable by individuals & 1211 & Employee contributions \\
\hline 1112 & Payable by corporations and other & 1212 & Employer contributions \\
\hline & enterprises & 1213 & Self-employed or nonemployed contributions \\
\hline 1113 & Unallocable & 1214 & Unallocable contributions \\
\hline 112 & Taxes on payroll and workforce & 122 & Other social contributions \\
\hline 113 & Taxes on property & 1221 & Employee contributions \\
\hline 1131 & Recurrent taxes on immovable property & 1222 & Employer contributions \\
\hline 1132 & Recurrent taxes on net wealth & 1223 & Imputed contributions \\
\hline 1133 & Estate, inheritance, and gift taxes & & \\
\hline 1134 & Taxes on financial and capital transactions & 13 & Grants \\
\hline 1135 & Other nonrecurrent taxes on property & 131 & From foreign governments \\
\hline 1136 & Other recurrent taxes on property & 1311 & Current \\
\hline 114 & Taxes on goods and services & 1312 & Capital \\
\hline 1141 & General taxes on goods and services & 132 & From international organizations \\
\hline 11411 & Value-added taxes & 1321 & Current \\
\hline 11412 & Sales taxes & 1322 & Capital \\
\hline 11413 & Turnover and other general taxes on goods & 133 & From other general government units \\
\hline & and services & 1331 & Current \\
\hline 1142 & Excises & 1332 & Capital \\
\hline 1143 & Profits of fiscal monopolies & 14 & Other revenue \\
\hline 1144 & Taxes on specific services & 141 & Property income \\
\hline 1145 & Taxes on use of goods and on permission to & 1411 & Interest \\
\hline & use goods or perform activities & 1412 & Dividends \\
\hline 11451 & Motor vehicle taxes & 1413 & Withdrawals from income of quasi- \\
\hline 11452 & Other taxes on use of goods and on & & corporations \\
\hline 1146 & $\begin{array}{l}\text { permission to use goods or perform activities } \\
\text { Other taxes on goods and services }\end{array}$ & 1414 & $\begin{array}{l}\text { Property income attributed to insurance } \\
\text { policyholders }\end{array}$ \\
\hline 115 & Taxes on international trade and transactions & 1415 & Rent \\
\hline 1151 & Customs and other import duties & 142 & Sales of goods and services \\
\hline 1152 & Taxes on exports & 1421 & Sales by market establishments \\
\hline 1153 & Profits of export or import monopolies & 1422 & Administrative fees \\
\hline 1154 & Exchange profits & 1423 & Incidental sales by nonmarket establishments \\
\hline 1155 & Exchange taxes & 1424 & Imputed sales of goods and services \\
\hline 1156 & Other taxes on international trade and & & Fines, penalties, and forfeits \\
\hline & transactions & 144 & Voluntary transfers other than grants \\
\hline 116 & Other taxes & 1441 & Current \\
\hline 1161 & Payable solely by business & 1442 & Capital \\
\hline 1162 & $\begin{array}{l}\text { Payable by other than business or } \\
\text { unidentifiable }\end{array}$ & 145 & Miscellaneous and unidentified revenue \\
\hline
\end{tabular}




\section{ANNEX III. GFSM 2001-Economic Classification of Expense}

\begin{tabular}{|c|c|c|c|}
\hline \multicolumn{4}{|c|}{ Expense } \\
\hline 21 & Compensation of employees & 27 & Social benefits \\
\hline 211 & Wages and salaries & 271 & Social security benefits \\
\hline 2111 & Wages and salaries in cash & 2711 & Social security benefits in cash \\
\hline 2112 & Wages and salaries in kind & 2712 & Social security benefits in kind \\
\hline 212 & Social contributions & 272 & Social assistance benefits \\
\hline 2121 & Actual social contributions & 2721 & Social assistance benefits in cash \\
\hline 2122 & Imputed social contributions & 2722 & Social assistance benefits in kind \\
\hline & & 273 & Employer social benefits \\
\hline 22 & Use of goods and services & 2731 & Employer social benefits in cash \\
\hline 23 & Consumption of fixed capital & 2732 & Employer social benefits in kind \\
\hline 24 & Interest & & Other expense \\
\hline 241 & To nonresidents & & Property expense other than interest \\
\hline 242 & To residents other than general government & 2811 & Dividends (public corporations only) \\
\hline 243 & To other general government units & 2812 & $\begin{array}{l}\text { Withdrawals from income of quasi- } \\
\text { corporations (public corporations only) }\end{array}$ \\
\hline 25 & Subsidies & 2813 & Property expense attributed to insurance \\
\hline 251 & To public corporations & & policyholders \\
\hline 2511 & To nonfinancial public corporations & 2814 & Rent \\
\hline 2512 & To financial public corporations & 282 & Miscellaneous other expense \\
\hline 252 & To private enterprises & 2821 & Current \\
\hline 2521 & To nonfinancial private enterprises & 2822 & Capital \\
\hline 2522 & To financial private enterprises & & \\
\hline 26 & Grants & & \\
\hline 261 & To foreign governments & & \\
\hline 2611 & Current & & \\
\hline 2612 & Capital & & \\
\hline 262 & To international organizations & & \\
\hline 2621 & Current & & \\
\hline 2622 & Capital & & \\
\hline 263 & To other general government units & & \\
\hline 2631 & Current & & \\
\hline 2632 & Capital & & \\
\hline
\end{tabular}




\section{ANNEX IV. GFSM 2001-Classification of Expense by Function of Government ${ }^{23}$}

\begin{tabular}{|c|c|c|c|}
\hline \multicolumn{4}{|c|}{ Total outlays } \\
\hline 701 & General public services & 706 & Housing and community amenities \\
\hline 7011 & Executive and legislative organs, financial and & 7061 & Housing development \\
\hline & fiscal affairs, external affairs & 7062 & Community development \\
\hline 7012 & Foreign economic aid & 7063 & Water supply \\
\hline 7013 & General services & 7064 & Street lighting \\
\hline 7014 & Basic research & 7065 & R\&D Housing and community amenities \\
\hline 7015 & R\&D ${ }^{1}$ General public services & 7066 & Housing and community amenities n.e.c. \\
\hline 7016 & General public services n.e.c. ${ }^{2}$ & & \\
\hline 7017 & Public debt transactions & 707 & Health \\
\hline 7018 & $\begin{array}{l}\text { Transfers of a general character between } \\
\text { different levels of government }\end{array}$ & 7071 & $\begin{array}{l}\text { Medical products, appliances, and } \\
\text { equipment }\end{array}$ \\
\hline & & 7072 & Outpatient services \\
\hline 702 & Defense & 7073 & Hospital services \\
\hline 7021 & Military defense & 7074 & Public health services \\
\hline 7022 & Civil defense & 7075 & R\&D Health \\
\hline 7023 & Foreign military aid & 7076 & Health n.e.c. \\
\hline 7024 & R\&D Defense & & \\
\hline 7025 & Defense n.e.c. & 708 & Recreation, culture, and religion \\
\hline & & 7081 & Recreational and sporting services \\
\hline 703 & Public order and safety & 7082 & Cultural services \\
\hline 7031 & Police services & 7083 & Broadcasting and publishing services \\
\hline 7032 & Fire protection services & 7084 & Religious and other community services \\
\hline 7033 & Law courts & 7085 & R\&D Recreation, culture, and religion \\
\hline 7034 & Prisons & 7086 & Recreation, culture, and religion n.e.c. \\
\hline 7035 & R\&D Public order and safety & & \\
\hline 7036 & Public order and safety n.e.c. & 709 & Education \\
\hline & & 7091 & Pre-primary and primary education \\
\hline 704 & Economic affairs & 7092 & Secondary education \\
\hline 7041 & General economic, commercial, and labor & 7093 & Postsecondary nontertiary education \\
\hline & affairs & 7094 & Tertiary education \\
\hline 7042 & Agriculture, forestry, fishing, and hunting & 7095 & Education not definable by level \\
\hline 7043 & Fuel and energy & 7096 & Subsidiary services to education \\
\hline 7044 & Mining, manufacturing, and construction & 7097 & R\&D Education \\
\hline 7045 & Transport & 7098 & Education n.e.c. \\
\hline 7046 & Communication & & \\
\hline 7047 & Other industries & 710 & Social protection \\
\hline 7048 & R\&D Economic affairs & 7101 & Sickness and disability \\
\hline 7049 & Economic affairs n.e.c. & 7102 & Old age \\
\hline 705 & Environmental protection & 7103 & Survivors \\
\hline 7051 & Waste management & 7104 & Family and children \\
\hline 7052 & Waste water management & 7105 & Unemployment \\
\hline 7053 & Pollution abatement & 7106 & Housing \\
\hline 7054 & Protection of biodiversity and landscape & 7107 & Social exclusion n.e.c. \\
\hline 7055 & R\&D Environmental protection & 7108 & R\&D Social protection \\
\hline 7056 & Environmental protection n.e.c. & 7109 & Social protection n.e.c. \\
\hline
\end{tabular}

${ }^{23}$ GFSM 2001 incorporates the Classification of the Functions of Government (COFOG) of the OECD and the UN. 